\title{
Children's Literature, Text and Theory: What are we interested in now?
}

\author{
John Stephens
}

1

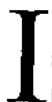
$\mathrm{n}$ the course of the nineteen-nineties, there has been a steady trickle of notable books which attempt to place children's literature within the context of those modern literary and cultural theories which post-date the various reader response criticisms, or within a particular facet of that newer body of theory (in particular, Hunt, 1991; Wall. 1991; Stephens, 1992; Nodelman, 1994/ 1996; McGillis, 1996; Nikolajeva, 1996).' Some of these books are still too recent to draw many conclusions about their impact by examining, say, citations in major journals dedicated to children's literature, but we might also think of such books as reflecting a more general interest in newer theoretical ideas as well as having a leading or introductory function. In other words, can we look more widely at the framing of text by theory within contemporary critical practice, and discern some answers to the question. What are we interested in now? A further question which remains more or less implicit in the first is, To what extent does current thinking and writing about children's literature conform with what the wider academic community of the humanities and social sciences perceives as 'usual practice' in research procedures? In this paper. I am going to address the question of current theoretical/ critical interest by focusing principally on the deployment of the term (and sometimes the concept) intertextuality in some recent periodical literature.

Major research projects (monographs; PhD theses) are. nowadays, theory-driven. This entails not just that a work will develop and argue a theory about something, but also that the thesis to be advanced will be situated within some kind of theoretical perspective. At its simplest, this will mean situation of the project within a 'school' of thought, a recognised critical orientation (though perhaps broadly defined - postcolonial criticism; French feminism; cultural materialism), or the ideas of an individual theoretician with contemporary currency. ${ }^{2}$ More complex theoretical perspectives evolve when the process becornes more reflexive and interrogates the categories of thought and the discursive practices employed, or when it uses existing theories and moves on to develop further perspectives. It is, of course, a truism that the most mundane short article will reflect a theory about text and world, no matter whether or not its author is conscious of this.

Papers 10: 22000
Children's literature scholars are less diffident about the idea of theory than they were a few years ago, but we share a certain reticence about it with other intellectual communities. In Literary Theory: a Very Shor Introduction Jonathan Culler reproduces a pertinent cartoon, a version of the conventional moment when a ycung women introduces her boyfriend to her father. The caption simply reads: 'You're a terrorist? Thank God. I understood Meg to say you were a theorist' (1997, p.16). The distinction between the contrasted terms here has often disappeared for the children's literature community during the past thirty-odd years. Having been accused of both vocations myseif, I'm obviously interested in why this should be so, and what are the actual theoretical underpinnings of the criticism which has been (and remains), in practice, the alternative. Culler, quite reasonably, I think, attributes the unease about theory to its endlessness and 'unmasterability' (1997, p. 16). There is more of it than any one person can ever know; you embrace it in the hope it will provide concepts to organise and understand the phenomena that interest you' (pp.16-17); and then it betrays you by calling into question the conclusions you reach and the premises they were based on.

But all that may only be a lesser element in the terrorist role of theory vis-a-vis children's literature. More threatening may be the propensity for modern theory, from social semiotics to psychoanalytic criticism, simply to sweep aside the kind of approach perhaps encapsulated in Peter Hunt's notion of 'childist criticism' (1984: 1991; 1996-97). The theoretical underpinnings of such approaches, I think, are empiricism and reader response criticism. Empiricism - roughly. the idea that we know the world by observing it objectively, and that ideas and concepts are built up by combining and abstracting from sense-data - had a long history in British intellectual life. lived on in literary criticism and historiography long after its influence in philosophy had diminished, and as far as I can see still seems to dominate its criticism of children's literature. ${ }^{3}$ It is apt to supplant any other critical perspective, except a residual reader response criticism, whenever actual children's actual use of a book becomes the primary criterion of value. Reader response Copyright Act 1968, copying this copyright material is prohibited without the permission of the owner or its exclusive licensee or agent or by way of a licence from Copyright Agency Limited. For information about such licences contact Copyright Agency Limited on (02) 93947600 (ph) or (02) 93947601 
criticism is still theoretically pervasive in secondary school English classes, but its academic swan song was probably as far back as 1980 , when both Tompkins and Suleiman and Crosman published major collections of essays in the field. Notoriously, Louise Rosenblatt, the most influential of reader response theorists on children's education, especially in North America, rated only passing mention in those collections, and did not influence academic theory. ${ }^{4}$ It will remain to be seen whether the embedded examples of reader response criticism in May (1995) and McGillis (1996) designate a similar swan song for reader response in children's literature criticism.

The intellectual equivalents of British empiricism in North America are formalist analysis/description and historicism, a similarity and difference that can be seen surfacing in Jill P. May's hostile review of Fox's critical anthology Celebrating Children 's Literature in Education (in The Lion and the Unicorn 1998, 237-41): her objection, in effect, is that Fox's selection over-represents British empiricism at the expense of North American historicism (which I understand to be a combination of literary history and social history). Slung as it is amongst the poles of formalism, historicism, empiricism and reader response criticism, it is perhaps not surprising that Children's Liserature in Education is intellectually the most timid of journals. Jill P. May's own Children's Literature and Critical Theory (1995) - an eclectic pastiche of New Criticism, historicism, myth criticism, and reader response criticism - is an epitome of North American criticism, inhabiting a curiously untheorised space somewhere in the early nineteen-seventies. I should comment that I don't have any special prejudice against historicism - though we should be far enough on from the work of Hayden White on historiography to be selfreflexive about its procedures and conscious of the metanarratives informing historiography. The opening sentence of Kordula Dunscombe's article in Papers (1998) on Louisa Anne Meredith is as ideologically fraught a piece of historiography as one might imagine, but at least it wears its ideology on its sleeve:

It is heartening to look back on Cl9th colonial literature for children and see, amongst the messages of domination, exploitation and general disrespect for the environment, that other paradigms of the land were also offered to child readers.

$(1998,2,16)$

The author positions herself by overtly favouring one model of land use over another, and one relationship between textuality and social ideology over another. acopting a position widely held in liberal Australian circles, but not necessarily by a majority of Australians. The positioning is cbvious in the contrasts within the strongly emotive language ('heartening ... disrespect'). II

So are people interested in anything else now? Logically, this could be addressed by looking at some of the current theory books: Maria Nikolajeva, for example, in Children's Literature Comes of Age (1996) brings together many of the perspectives from semiotic and narrative theories which have been increasingly if siowly seeping into children's literature criticism over the past decade. Instead of following that path, and examining a small number of individual voices (including my own), I've sought a wider representation of practices by taking the most recent 1998 issue of four journals to see what kinds of theoretical, conceptual or critical approaches informed their articles (excluding reviews, regular columns, and other such genres): Children's Literature 26, the general issue of The Lion and the Unicorn (22,2), Children's Literature in Education (29,2), and Papers (8,2). This is a small sample of twenty-four articles. I found that if there was a common thread to try to tease out it was the idea of intertextuality, which had a central function in some articies, was evoked in others, and seemed to be a significant absence in two where texts had been placed in loose dialogic relationships. Jonathan Culler (with more than a hint of a sneer) refers to intertextuality as 'a fancy name' for the proposition that 'works are made out of other works: made possible by prior works which they take up, repeat, challenge, transform. . . . A work exists between and ameng other texts, through its relations to them' $(1997$, p.34). Maria Nikolajeva, in a parenthetic remark in her article in The Lion and the Unicorn issue, expresses a preference for Bakhtin's original term 'dialogics' (p.232), but it now seems too late to go back. 
Intertextuality has been a God-send for innumerable people, because they can deploy a fashionable new word without having to absorb a new concept. Instead of saying 'allusion', one can now say 'intertextual reference', and not worry too much about that notion of existence 'between and among other texts' Culier writes of. As I will argue below, there is a strand in contemporary picture book production which presupposes an awareness of intertextuality as meaning situated in the process of interaction between texts, in the spaces between texts (see Stephens, 1992, p. 88). Very pertinent to such books, too. is Nikolajeva's reminder that the concept is about 'codes' and conversations between art works, rather than about influences and causes (1996, pp.153-54), and that the range of a work's possible intertexts goes well beyond literary or written texts. The concept of dialogism is of enormous importance, and is getting a lot of attention in discussion of picture books, and I will return to it shortly as the focus for the rest of this paper.

Before I do, however, i will briefly characterise what eise $\mathrm{I}$ found in the journals. What appears in a particular issue is, of course, largely accidental; I discarded the most recent issue of Children's Literature Association Quarterly because it was a special issue on medieva! literature and effectively committed contributors to a historicist frame. The four I examined confirm that what we are mainly interested in is fiction. Children's Literature surprised by including two articles about poetry. One turns out to be a historical study of the distribution of Coleridge's poems in books for children in the niteteenth century, but the other, John Rieder's 'Edward Lear's limericks: The function of children's nonsense poetry' is in terms of its theoretical affiliations - especially in its deployment of Bakhtin's theory of carnival - the most theoretically advanced piece in the issue. Papers reprints an article by Robyn McCallum dealing with that equally rare topic, children's film; film gets a passing mention in a couple of articles in Lion and Unicorn, but only with reference to content, not as form or genre. We are still not interested in children's drama. That fiction is the predominant focus of discourses about children's literature may in itself largely explain why those discourses are critically oriented towards an 'older' mode - content analysis within the frame of categories such as character, plot, setting, theme, point of view and style.

I categorised the articles according to four descriptors: the focus - author/period/genre studies, or particular text types (fiction, picture book, etc.); whether the writer deployed a theoretical/critical orientation in existence before 1980 (historicism, formalist analysis/description or reader response criticism); the principal socio-cultural discourses that concern criticism of children's literature (ethnicity/race, gender, class. family); and whether the writer deployed analytical concepts that had come into use since the rise of the reader response theories. As far as possible. I attempted to restrict attributions of the fourth category to systemic uses of theory or concept, and hence to exclude non-functional citation. For example, Ellerby (Lion and Unicorn, p.211) cites Paul Smith's important work on subjectivity, Discerning the Subject (1988), but this is essentially an ornamental citation, a common vice often to be found in contemporary criticism. Concepts of subjectivity are very pertinent to the focus text here, Rushdie's Haroun and the Sea of Stories; Ellerby could have found in Smith a useful version of a common formulation of the concept: that an individual's consciousness and sense of identity is formed in dialogue with others and with the discourses and ideologies that constitute the society and culture that individuals inhabit (see also McCallum 1999. Chap.1). An effective reading of Haroun and the Sea of Stories might develop this (it is not a difficult idea, after all), and further relate it to theories of intertextuality and metafiction, but in this case the writer apparently has no functional access to theories Rushdie himself has been manifestly deploying since at least Midnight's Children, and simply describes content. A contrast is readily available in Nikolajeva's article, which is instead concerned with how contemporary fictions demand a grasp of appropriate theories as a basic step toward understanding them. A third possibility is afforded by Hanlon's paper (in Children 's Literature) on Jane Yolen's stories. This makes no pretensions to being informed by contemporary theory, but might have been taken beyond a generally descriptive (and over-long) survey nuanced by gender issues if she had deployed a vigorous theory of intertextuality instead of a lightweight 'influences and paredies' model which resides in placing texts side by side and describing them. Hutcheon's $A$ 
Theory of Parody (1985) offers an appropriate theoretical linking of parody and intertextuality.

It is not my intention either to privilege or to pejorate in themselves the various discourses I identified and attributed, though various strengths and weaknesses are evident. Most of us (and $I$ hasten to include myself in that 'us') ground our critical procedures in some elements of formalism - attention to structures, alertness to complexities of meaning, an interest in the mode of being of a text from moment to moment. This remains the staple of children's literature criticism. Of course it is often quite poorly done, and I might have taken the descriptor to a further degree of delicacy, discriminating between self-reflexive formalisms which are kept informed by reference to current developments in literary and cultural theory, semiotics, linguistics, and so on, and formalisms which collapse into narrative and descriptiveness. The term and concept of intertextuality can again be a key indicator here, though it in fact doesn't occur in the most theoretically confused of the articles I looked at, that by Lehman and Crook in Children's Literature in Education. Declaring itself to slough off the stultifying practices of formalism (literary criticism 'too analytical, formal, and unspontaneous', p. 70), and to embrace instead 'literary literacy' within a reader response frame, the paper offers an exercise in what other people might recognise as aleatory intertextuality (pursuing comparison between randomly gathered texts), and an analytical procedure attention to themes, fanguage, symbols and structure which is actually a filleted version of early New Criticism. Once again an immediate contrast is available with the article which follows in the journal, Clare Bradford's careful, well-argued use of formalist analysis as a basis for gender studies, through a precise deployment of verbal, narrative and visual codes in some Anthony Browne picture books, and a deft reading of the selfconscious dialogism of the illustrations. The Lehman/ Crook kind of theoretical monstrosity seems rather harmless, as it can be read with the mind at most half engaged and the books remain recognisable. We tend to blench at non-functional theoretical pastiche rather more when some young scholar cobbles together half a dozen incompatible and incomprehensible bits of poststructuralism to teach us old fogies how we should be talking about text. They are equally inept, of course, both failing to grasp a central point about theory: to quote Culler's useful little book again, 'it involves complex relations of a systematic kind among a number of factors' $(1997$, p.3).

Table 1 summarises the distribution of categories. (see p.16)

What is disclosed by reading through the sample of twenty-four articles can be stated very briefly. We are interested in fiction and literary history, often in tandem; we are not much interested in poetry, film, drama, of theory in itself; we appreach texts from historicist and formalist stances; we are modern in our thematic concerns with socic-cultural discourses of ethnicity/race, gender and class (but the fiction itseif is apt to dictate that); and critical practice is taking on board some concepts from modern cultural and literary theories. As I said earlier, the most common of these is intertextuality, which is more characteristically deployed in relation to smaller and/or visual texts than to fiction.

III

The two articles which best demonstrate a systemic absorption of the concept of intertextuality into critical practice are those of Bradford and Lewis in Children's Liserature in Education, though in Lewis's case it has been implicitly refashioned on the model of the "telling gaps' filled by readers which is a central plank of reader response theories derived from the work of Wolfgang Iser. The important thing for my present purposes. though, is that the principle is being examined at work in relation to picture books. This has been one of the more exciting features of recent modern books and the critical responses to them, and is why picture book criticism is a site for some of the most adventurous thinking in the area. Anthony Browne and Colin McNaughton are two authorillustrators who habitually produce obviously intertextua! artwork, though they are not alone. Browne, however, has received more attention than anyone else, largely through several published and unpublished papers by Jane Doonan. The American author-illustrator Alien Say has produced some remarkable examples, especially in Grandfather's Journey (1993) and Emma's Rug (1996).' Say was awarded the Caldecott Medal for Grandfather's 
Table 1

\begin{tabular}{|c|c|c|c|}
\hline Article focus & $\begin{array}{l}\text { Theoretical/ } \\
\text { critical } \\
\text { orientation in } \\
\text { existence before } \\
1980\end{array}$ & $\begin{array}{l}\text { Socio-cultural } \\
\text { discourses invoked } \\
\text { (ethnicity/race, } \\
\text { gender, class, family) }\end{array}$ & $\begin{array}{l}\text { Theory since reader } \\
\text { response }\end{array}$ \\
\hline $\begin{array}{l}\text { Author, Period or } \\
\text { Genre survey } \\
\text { (incl. multiple text } \\
\text { types) }=9\end{array}$ & $\begin{array}{l}\text { historicist } \\
\text { and/or } \\
\text { formalist analysis }\end{array}$ & $\begin{array}{l}\text { farnily }=1 \\
\text { gender }=3\end{array}$ & intertextuality $=1$ \\
\hline $\begin{array}{l}\text { Theory (of fiction) } \\
=1\end{array}$ & & & $\begin{array}{l}\text { narrativity (focalisation, } \\
\text { metafiction, intertextuality, } \\
\text { etc.); theory of subjectivity; } \\
\text { genre }\end{array}$ \\
\hline Fiction $=3$ & $\begin{array}{l}\text { historicist } \\
\text { formalism }\end{array}$ & $\begin{array}{l}\text { ethnicity/gender/ } \\
\text { class }=1 \\
\text { race }=1\end{array}$ & \\
\hline Fiction $=3$ & formalism & gender $=2$ & $\begin{array}{l}\text { intertext uality } \\
\text { psychoanalytic criticism } \\
\text { (with gender) }=1\end{array}$ \\
\hline Fiction $=1$ & $\begin{array}{l}\text { formalism/reader } \\
\text { response }\end{array}$ & & \\
\hline Fiction $=1$ & historicism & gender & intertextuality \\
\hline Poetry $=2$ & $\begin{array}{l}\text { historicist }(=1) \\
\text { formalist analysis } \\
(=1)\end{array}$ & . & $\begin{array}{l}\text { Bakhtinian theory (on } \\
\text { formalist ground) }=1\end{array}$ \\
\hline Film $=1$ & formalism & $\begin{array}{l}\text { alienation } \\
\text { ethnicity }\end{array}$ & $\begin{array}{l}\text { cultural studies; post- } \\
\text { colonial criticism; theory of } \\
\text { subjectivity }\end{array}$ \\
\hline \multicolumn{4}{|l|}{ Drama $=0$} \\
\hline Picture Books = 3 & $\begin{array}{l}\text { reader response } \\
\text { [DL] } \\
\text { formalism [CB] } \\
\text { reader response } \\
\text { [LS] }\end{array}$ & gender [CB] & $\begin{array}{l}\text { Intertextuality/Metafiction/ } \\
\text { Narrative theory [DL] } \\
\text { Intertextuality/Feminism } \\
\text { [CB] } \\
\text { Semiotics [LS] }\end{array}$ \\
\hline
\end{tabular}


Journey, and a more recent Caldecott Medal winner, Paul O. Zelinsky's Rapunzel creates some mind-teasing dialogues between the Grimm fairytale and Renaissance paintings illustrating the life of the Virgin Mary. For example, the prince's entry into the tower is modelled on versions of the Annunciation, one of the most frequently depicted sacred incidents; and the final page, depicting the reunited lovers and their two children, is a transformation of Raphael's Madonna and Child with the Infant St John (La Belle Jardiniere). The dialogue must also extend to Tryna Schart Hyman's Rapunzel (1982) as well, in that Hyman has also explored the analogy between the entrance of the prince into Rapunzel's tower and the Annunciation. Both texts lead beyond questions of how the world constructs and reacts to a situation in which an 'impossible' pregnancy eventuates, though that is an obvious place to start, and Zelinsky prompts this with an inverted reprise of the 'Annunciation' scene when Rapunzel's stepmother discovers the pregnancy.

The example I want to consider now, however, is Anthony Browne's Willy the Dreamer." Not only is this perhaps the most exciting yet of Browne's intertextual playing fields, a discussion of it inevitably enters a dialogic relationship with the articles by Bradford and Lewis, through a shared joke about bananas and Browne's own habit of cross-referencing amongst his books. Willy the Dreamer links both with the earlier books about Willy and with The Big Baby. A central function of intertextuality pointed to in the Bradford and Lewis articles is that it makes connections, referring readers outside the present text to other worlds, and in this case in particular it sets up dialogic relationships amongst the ways audiences negotiate different kinds of cultural formations. Lewis stresses the intertexts in popular culture suggested by McNaughton, but because the focus text, Oops! is also a fractured fairy tale, it enters the domain where fairy tale itself mediates popular culture and high culture texts. Zelinsky's Rapunzel is only an extreme example pushing in one of these directions. Audiences are encouraged to reflect on how stories work, and how meaning in texts and in the world emerges and evolves in dialogic forms. When the wolf of Oops!, in pursuit of the pig who has slipped out of the 'Three Little Pigs' fairy tale and appears instead as Red Riding Hood, recalls alternative versions of wolf-and-pig stories told to him by his mother, it becomes almost unavoidable to invoke Allan Ahlberg's Ten in a Bed (1983) and Catherine Storr's Clever Polly and the Wolfseries (1955-1990), older versions of wolfand-dinner stories which are still in print. That audiences may encounter these other texts, before $\mathrm{cr}$ after this one, emphasises how intertextuality is not a matter of things occurring in a specific order, but existing in a potential or actualised dialogic relationship. Bradford takes the implication of dialogism still further, and demonstrates how the dialogic play of meanings discloses the ideologies which underpin representation.

As Lewis points out, the semiotic conjunction of bananas and pratfalls recurs in Oops!. The first appearance of the banana skin evokes the conjunction as an absence, as Preston pig moralises about the danger of misplaced banana skins. In the final pursuit scene, when Father Pig/ woodcutter chases the wolf out of the book, the previous banana scene instantiates an expectation that the wolf will slip on the skin where it still lies. He does, but we have to turn to the front cover to see it. The back cover shows the pigs in a heap after Father Pig has tripped over a rock, which is just as evident in the penultimate scene. but not as an instantiated danger. The effect is a small lesson in the principles of teleology, of discerning patterns and final causes backwards from the end, in counterpoint to the pre-textual knowledge of how the Red Riding Hood story should come out. But the intertextual dialogue with Ahlberg and Storr reinforces an insight implicit in the moment when Preston speaks the Wolf's lines ('Grandma, what big eyes you've got....'): the relationship between structures and elements within structures is apt to be unstable - the frame may not survive a variation of its parts. In 'Thinking in threes' from Last Stories of Polly and the Wolf (1990), for example, Polly explains to the Wolf, with impressively logical illogic, that his plan to trap her by reinstantiating the story of Goldilocks had to fail because the 'rule of three' was broken: there were three bears, but only one wolf.

In Willy the Dreamer, nothing is immune from turning into a barana, a pattern weli established by the fourth opening, where Willy dreams he is a sumo wrestler. This constitutes one of the less explicit intertextual fields in 
the book. It links to the audience's world knowledge about the sport, gleaned from television, perhaps, to the discourses of wimp and bully in Browne's earlier Willy books, and to inexplicit narratives about the unexpected victory of the little guy. Oops! is one such narrative. though that isn't any stronger reason for bringing the two books together than is the coincidence of bananas. Their relationship is aleatory, but the dialogue between them can be meaningful. The crucial banana lies on the floor of the wrestling ring just beside the left foot of tiny Willy's monstrous opponent. It is not just any banana, however. It is a banana peel lying where it should not be. The scene depicts great tension, with the vectors formed by the represented spectators' gazes, including thuse of Willy's beloved Milly and his friend Hugh, fixed in awe on the unseen face of the opponent. Only Wiliy's left eye is fixed elsewhere, forward off the page, locked in an alarmed reciprocal gaze with the spectator. The spectator is able to extrapolate a possible action in a moment not yet happened. In simple terms, we can predict ahead, on the basis of cues and the wider context. But we cannot know. The closure of Oops! demonstrates that teleologies are produced in story, rather than being innate occurrences. As we move further into Willy the Dreamer, it becomes clear that Willy's dreams are a mixture of fantasy and nightmare. and some may be indeterminate. Hence the sumo wrestler dream constitutes a subtle narrative and ideological complex, teasing us into irresolution, nudging at our fantasies, our insecurities. I can't offer a resolution, because I think the picture thrusts its spectators into a terrain of unbounded dialogism.

It would be a joy to examine every opening in Willy the Dreamer here. I have elsewhere commented on the effect of modality shifts in picture books by Browne and by Say, and that is again a particularly interesting facet of this book as pictures interact with those on facing pages, offering. as is Browne's practice, dialogic relations between realism, surrealism and hyperrealism in a foregrounding of representation that keeps spectators engaged with the process as much as the product. But space won't permit such an indulgence, so I will conclude with a brief comment on one of the more nightmarish scenes, the 'strange landscape' picture in which Browne literally constructs a pastiche of three Salvador Dali paintings and one Magritte. (Within the frame painting, Dali's The Persistence of Memory, he embeds Dali's Sleep, the memory chest from the Spanish Civil War nightmare Spain, 1936-38, and one of Magritte's 'flaming objects', the latter now, of course, a kind of banana flambé.) Close to the centre of the page is an extremely small figure of Willy, once again engaging the spectator in reciprocal gaze and in doing so physically pulling us towards the plane of the page. The objects disconcert by their refusal to resolve into interpretable wholes. The watch which occupied the left foreground in The Persistence of Memory has become a fried egg with a banana-shaped yolk. Other bananas substituted for Dali's objects seem unstable: they are ofeflated, tuming into things, such as a fish, a goose, a horse-head, a paint-brush (?). The chest has undergone a double change: Dali's red handkerchief, a tragic metaphor for war, has become a deflated banana; its shadow, the shadow of a snake. There is an apparent allusion in the alignment of the intruded objects (Sleep and the chest) to an opening in The Big Baby, where Mrs Young's shadow is cast, in a different form, over a reproduction of Dali's Sleep, replicating the combination of sleep and horror Bradford pointed to in her discussion of that opening (1998, p.91), but shifting the relationship by softening and feminising the face on the Sleep/banana figure and transforming the landscape behind it into a tomb-effigy of a sleeping gorilla. In a way, this may be a more focused application of intertextual dialogism, in that we can interpret Browne's pastiche without knowing its sources because Willy, and his obsession with bananas, is centred as a reference point. His world, like the bananas, has deflated, lost reference, entered a space of horror. The dialogic relationship with Dali and Magritte might, at some future time, prove very useful in reading those particular paintings. That, clearly enough, is a further and practical function of intertextuality in children's literature, and one of which authors and illustrators are well aware. For example, the hope of having such an effect is declared explicitly by Zelinsky in the end-note to his Rapunzel: 'It would please me if my pictures served in some measure to spur an interest in the magnificent art from which I have drawn' (n.p.).

Finally. a good reason why scholars might well use intertextuality as a stepping-stone towards other aspects 
of contemporary theory is that it opens windows. An obvious example suggested by Willy the Dreamer, when Willy dreams of being a painter and a writer, is metafiction, with which intertextuality often overlaps. The two pertinent openings are linked by citations of Magritte's Ceci n'est pas une pipe; are built on obviously selfreflexive works (a bundle of Magritte paintings; Lewis Carroll's Alice books); make outrageous substitutions of gorillas and bananas for familiar art works; and foreground internal modality shifts (the 'Gorilla de Milo' is simultaneously a painting and a sculpture, through a clever dissolution of pictorial plane; Willy the writer has entered the scene he is writing, in a classic metafictive diegetic shift). Intertextuality offers insights into the representation of subjectivity, perhaps the central theme of Willy the Dreamer. It prompts thoughts about Jung, Freud and psychoanalysis, when Willy the explorer (as Stanley) encounters Freud enclosed within a nuclear family sitting on a pink couch inside a Rousseau painting; it poses questions about the relationships between high culture and low culture in the ways we make sense of the world; and many, many other things. The interest in intertextuality, then, not only responds to what producers of texts are doing, and what readers bring to those texts, but when employed as a thought-provoking concept rather than an ornamental term, can be a stepping-stone to other ways of thinking about children's texts.

\section{NOTES}

1. The process had begun in the 1980 s, with such works as Jacqueline Rose's The Case of Peter Pan (London, Macmillan, 1984) and Zohar Shavit's Poetics of Children's Literature (Athens. Georgia, University of Georgia Press, 1986). Rose has proved the more quotable in subsequent criticism, but the contribution of the book to the theoretical conceptualisation of children's literature is in fact minimal.

2. Consider, for example, the extent to which Karin Lesnik-Oberstein's Children's Literature: Criticism and the Fictional Child is mapped onto Terry Eagleton's Literary Theory.

3. At least so it seems from 'outside' the culture. When delivering her Oxford Amnesty Lecture in 1992. Julia
Kristeva began by saying she found it 'a perilous enterprise' to talk about subjectivity to 'an English audience - brought up on empiricism and logical positivism ' (1993, p. 148). Empiricism is what underpins the pragmatism (p.10) of Hunt's Criticism. Theory and Children's Literature and makes it such a peculiarly British work.

4. The classic text for children's literature was Aidan Chambers' 'The Reader in the Book' (1977). See further Stephens, 1992:10, and Benton, 1996: 84.

5. For a discussion of transformations of works by van Gogh, Vermeer, Munch, Bosch and Monet in Emma's Rug, see my 'Modality and space in picture book art: Allen Say's Emma's Rug', forthcoming in CREATA.

6. Since this piece was written, Jane Doonan has illuminatingly discussed intertextual reference in Willy the Dreamer in The Lion and the Unicorn 23, 1(1999). My argument here has a different focus, so I have left it as originally written.

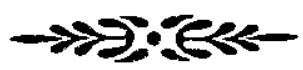

\section{REFERENCES}

Ahlberg, Allan Ten in a Bed. London, Granada.

Benton, Michael (1996) 'Reader-response criticism', in Peter Hunt(ed)/nternational Companion Encyclopedia ofChildren's Literature. London. Routledge, pp.71-88.

Bradiord, C. (1998) 'Playing with father: Anthony Browne's picture books and the masculine', Children's Literature in Education 29, 2, 79-96.

Browne, Anthony (1997) Willy the Dreamer. London. Walker Books.

Culler, Jonathan (1997) Literary Theory: A Very Short Introduction. Oxford, Oxford University Press.

Doonan, jane (1999) 'Drawing out ideas: A second decade of the work of Anthony Browne', The Lion and the Unicorn 23, 1, 30-56.

Dunscombe, K. (1998) 'In the Service of Infinitude and 
Glorious Creation: the Nature Writing of Louisa Anne Meredith', Papers: Explorations into Children's Literature 8, 2, 16-30.

Ellerby, J. M. (1998) 'Fiction under siege: Rushdie's quest for narrative emancipation in Haroun and the Sea of Stories', The Lion and the Unicorn 22, 2, 211-220.

Hanlon, T. L. (1998) "To sleep, perchance to dream": Sleeping Beauties and wide-awakeplain Janes in the stories of Jane Yolen', Children's Literature 26, 140-67.

Hunt, P. (1984) 'Childist criticism: the subculture of the child, the book, and the critic'. Signal 43, 42-59.

Hunt. Peter (1991) Criticism, Theory and Children's Literature. Oxford, Basil Blackwell.

Hunt, P. (1996-97) 'Passing on the past: the problem of books that are for children and that were for children', Children's Literature Association Quarterly 21, 4. 200-202.

Hutcheon, Linda (1985) $A$ Theory of Parody. New York and London, Methuen.

Kristeva, Julia (1993) 'The speaking subject is not innocent', in Barbara Johnson (ed) Freedom and Interpretation: The Oxford Amnesty Lectures, 1992. New York, Basic Books, pp.147-74.

Lehman, B. A. and Crook, P. (1998) 'Doubletalk: a literary pairing of The Giver and We Are All in the Dumps with Jack and Guy'. Children 's Literature in Education 29, 2, 69-78.

May, J. (1995) Children's Literature and Critical Theory: Reading and Writing for Undersianding. New York, Oxford University Press.

McCallum, Robyn (1999) Ideologies of Identity in Adolescent Fiction. New York, Garland Publishing.

McGillis, Roderick (1996) The Nimble Reader: Literary Theory and Children's Literature. London. Twayne.

McNaughton, Colin (1996) Oops! London, Andersen Press.

Nikolajeva, Maria (1996) Children's Literature Comes of Age: Toward a New Aesthetic. New York, Garland
Publishing.

Say, Ailen (1993) Grandfather's Journey. Boston, Houghton Mifflin Company.

Say, Allen (1996) Emma's Rug. Boston, Houghton Mifflin Company.

Smith, P. (1988) Discerning the Subject. Minneapolis: University of Minnesota Press.

Stephens, John (1992) Language and Ideology in Children's Fiction. London and New York, Longman.

Stephens, John, and McCallum, Robyn (1998) Retelling Stories, Framing Culture: Traditional Story and Metanarratives in Children's Literature. New York, Garland Publishing.

Storr, Catherine (1990) Last Stories of Polly and the Wolf. London, Faber and Faber.

Suleiman, Susan, and Crosman, Inge (eds) (1980) The Reader in the Text: Essays on Audience and Interpretation. Princeton, Princeton University Press.

Tompkins, Jane P. (1980) Reader Response Criticism: From Formalism to Post-structuralism. Baltimore and London. The Johns Hopkins University Press.

Wall, Barbara (1991) The Narrator's Voice: The Dilemma of Children's Fiction. London, Macmillan.

Zelinsky, Paul O. (1997) Rapunzel. New York, Dutton Children's Books.

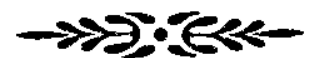




\section{BIOGRAPHICAL NOTE}

John Stephens teaches and researches children's literature in the English Department at Macquarie University. $\mathrm{He}$ is the author of Language and Ideology in Children's Fiction, two books about discourse analysis, co-author (with Robyn McCallum) of Retelling Stories, Framing Culture: Traditional Stories and Metanarratives in Children's Literature, and has written around sixty articles about children's (and other) literature.

\section{$\rightarrow 20:$}

\section{ACKNOWLEDGEMENT}

This article was first published in: Susan Clancy with David Gilbey (eds) (1999) Something to Crow About: New Perspectives in Literature for Young People. Wagga Wagga, Centre for Information Studies, Charles Sturt University in association with ACLAR. It is reproduced with the permission of the author and publisher.

Copies of the collection of papers in Something to Crow About may be ordered from Centre for Information Studies, Locked Bag 600, Wagga Wagga NSW 2678.

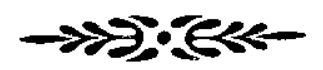

